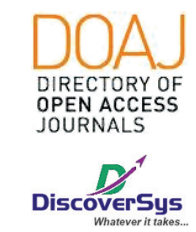

Published by DiscoverSys

\section{The correlation between demography and clinical status based on WHO staging in MSM HIV patients at Bali Medical Centre}

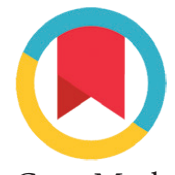

CrossMark

\author{
Dhanesh Sukumar Nair, ${ }^{1 *}$ I Nyoman Sutarsa, ${ }^{2}$ A A Sagung Sawitri, ${ }^{3}$ Komang Ayu Kartika Sari ${ }^{4}$
}

\section{ABSTRACT}

Background: HIV stands for human immunodeficiency virus which is in the category of lentivirus (a subgroup of retrovirus) that causes HIV infection and can lead to acquired immunodeficiency syndrome (AIDS). HIV affects specific cells of the immune system, called CD4 cells, or T cells. Over time, if left untreated, HIV can destroy so many of these cells that the body would not be able to fight off infections and disease. However, with proper medical care, HIV can be controlled. Treatment for HIV is called antiretroviral therapy (ART). It involves taking a combination of HIV medicines (called an HIV regimen) every day. Today, a person who diagnosed with HIV before the disease is far advanced and who gets and stays on ART can live a nearly normal lifespan.

Aim: This study aims to investigate and analyze the predictors that influence WHO staging of homosexual MSM HIV patients treated at the
BMC hospital in Bali. Indonesia, and to determine the factors that lead to differences in the WHO staging in MSM patients with HIV.

Method: This study used a retrospective cohort method using secondary data from BMC Hospital. The sample population for this research is MSM HIV patients treated at the BMC hospital in Bali. Using the total sampling method yielded 271 samples.

Result and Conclusion: the HIV incidence is a serious matter in Indonesia. One of the underlying factors for the delayed diagnosis of HIV is the lack of knowledge about the improved prognosis of early ARV treatment and a fear of being stigmatized by the community. Increased availability of HIV testing at hospitals, combined with enhanced knowledge of the prognosis of HIV treatment among crucial affected population, and the community at large and may improve earlier testing.
${ }^{1}$ Medical Science Study Program, Faculty of Medicine, Universitas Udayana

${ }^{2}$ Department of Preventive and Familly Medicine, Faculty of Medicine, Universitas Udayana

*Corespondence to: Dhanesh Sukumar Nair, Medical Science Study Program, Faculty of Medicine, Universitas Udayana dhaneshsukumar@yahoo.com

Received: 2018-04-06 Accepted: 2018-08-26 Published: 2019-08-01

Keywords: Human Immunodeficiency Virus, MSM, CD4 count, WHO staging

Cite This Article: Nair, D.S., Sutarsa, I.N., Sawitri, A.A.S., Sari, K.A.K. 2019. The correlation between demography and clinical status based on WHO staging in MSM HIV patients at Bali Medical Centre. Bali. Intisari Sains Medis 10(2): 188-193. D0I: 10.15562/ism.v10i2.202

\section{INTRODUCTION}

Among infectious diseases, human immunodeficiency virus (HIV) infection, which eventually results in acquired immune deficiency syndrome (AIDS), remains a global health problem. ${ }^{1}$ Infection with the human immunodeficiency virus (HIV) produces a prolonged, gradually progressive illness that eventually leads to opportunistic infections, malignancy, and death. The illness may last ten years or longer and is usually asymptomatic for the first several years. ${ }^{2}$ The human immunodeficiency virus (HIV) is a recent epidemic and was only first identified in the mid-1980s. Since then, it has become evident that HIV is an efficient negative moderator of host immune function with deadly consequences. It is estimated that nearly 60 million people have died from the consequences of the virus since the mid-1980s. ${ }^{3}$

Indonesia, a country with a population of 237.5 million in 2010 has an estimated HIV prevalence of $0.27 \%$ among the $15-49$ years age group. Indonesia's HIV and AIDS epidemic is concentrated amongst key affected population resulting from a mix of two modes of transmissions, sexual transmission, and drug injecting. In the year 2014, a total of 142,950 cases of HIV was diagnosed in Indonesia. ${ }^{4}$

The main population of this infectious disease occurred among people who fall under the category of people who inject drugs (PWID), sex workers (FSW), men who have sex with men (MSM) and transgenders (WARIA). The population that faces the highest risk of HIV infection was found to be the MSM group. The HIV epidemic situation in Indonesia is predicted to increase, especially among the most at-risk populations. ${ }^{5}$

Figure 1 which shows a distribution map of HIV and AIDS across the country where infection has been reported in 300 districts in 32 provinces. The map shows an uneven distribution with higher concentrations in urban areas. Tanah Papua (the two provinces of Papua and West Papua), Jakarta and Bali lead in the rate of new HIV cases per 100,000 people (Figure 2). Indonesia's Ministry of Health projections show that without acceleration of HIV prevention programmes, over half a million people in Indonesia will be HIV positive by $2014{ }^{6}$ 
There were an estimated 76000 new HIV infections in 2012. The number of people with access to antiretroviral therapy rose to just under 40000 in 2013 (a 27\% increase from 2012). While there may be signs that epidemics among sex workers and people who use drugs are stabilizing in some areas, HIV prevalence among men who have sex with men has significantly increased nationally, from $5.3 \%$ in 2007 to $8.5 \%$ in 2011 , and in Jakarta from $8.1 \%$ in 2007 to $17.2 \%$ in 2011, according to national Integrated Biological and Behavioural Surveillance 2007 and 2011 data. $^{?}$

Based on data from (BPS Central Java province in 2012), the population of Java is as busy as $32,643,612$ people. The cumulative number of HIV in Java from 1993 to June 30, 2012, is as much as 5.301 cases. Based on these risk factors, heterosexual 1,886 cases (79, 3\%), IDU: 272 cases (11.4\%), homosexual 96 cases (4\%), perinatal 117 cases (4.9\%) and transfusion 8 cases (0.3\%). MSM population contributes a sizable population to cope with HIV. ${ }^{5}$

\section{METHOD}

This is a retrospective cohort study as well as an epidemiological study in which the participating individual is classified as having several outcomes (cases). The issue may be a particular disease, and the history of the patient is examined to determine factors that may be associated with these results. Advantages of this research are that it usually requires a short time for the completion and implementation of rare diseases. The study was conducted through secondary data obtained from BMC Hospital Bali in early of December 2015.

Table 1 The estimated number of at-risk population in 2012

\begin{tabular}{lc}
\hline Population & Estimates \\
\hline People who inject drugs (PWID) & 74,328 \\
Sex workers (FSW) & 229,856 \\
Men who have sex with men (MSM) & $1,095,970$ \\
Transgender (WARIA) & 37,998 \\
\hline
\end{tabular}

Samples as many as 271 were patients who had been on antiretroviral therapy for at least 6 months prior to data collection from 2010 to 2014. The data were the latest medical records of HIV patients with WHO staging levels at BMC hospital from 2010-2014. The medical record data was already available at the BMC hospital in E-file format. Socio-demographic data including date of birth, gender, marital status, level of education, religion and sub-location of residence were collected. Trained clinicians collected clinical data including WHO staging, ART regimen, drug substitutions, drug pick updates and appointments. Hematology and CD4 T-cell count data were also counted.

\section{RESULTS AND DISCUSSION}

\section{Age Categorization}

Figure 3 showed the distribution of patients by age group by the quantity and by percentage respectively. It can be noted that out of 271 patients, 160 were between the age of 20-29 years old which accounted for $59 \%$. Approximately $95 \%$ of patients were between the period of 20 to 49 years old. This result is consistent with other works reported in South Asia ${ }^{6,8}$ and globally. ${ }^{9}$

\section{Body Weight Distribution}

Figure 4 showed the distribution of the body weight of patients. However, the height of patients was not captured in this data, and the Body Mass Index could not be compared. It can be observed that $56 \%$ of the patients show a low body weight of under $60 \mathrm{kgs}$ which is below average for males. This could indicate weight loss generally experienced by HIV patients. ${ }^{1,11}$

\section{Sexual Orientation}

As this study was concentrated on Homosexual patients, the numbers in the population of data are also corresponding as shown in figure 5 . However, there are also patients that have been bisexual and small numbers that declared to be heterosexual.

Most studies indicate that the MSM category is at the highest risk for contracting HIV. Social stigmas and discrimination against homosexuality prevent

Table 2 Comparison between clinical staging and Immunosuppression levels of patients

\begin{tabular}{lcccc}
\hline Stage & $\begin{array}{c}\text { Immuno-suppression } \\
\text { Stage 1 }\end{array}$ & $\begin{array}{c}\text { Immuno-suppression } \\
\text { Stage 2 }\end{array}$ & $\begin{array}{c}\text { Immuno-suppression } \\
\text { Stage 3 }\end{array}$ & $\begin{array}{c}\text { Immuno-suppression } \\
\text { Stage 4 }\end{array}$ \\
\hline Clinical Stage 1 & 46 & 61 & 90 & 39 \\
Clinical Stage 2 & 1 & 3 & 0 & 8 \\
Clinical Stage 3 & 1 & 2 & 3 & 12 \\
Clinical Stage 4 & 0 & 0 & 1 & 236 \\
TOTAL & 48 & 66 & 94 & 21 \\
\hline
\end{tabular}




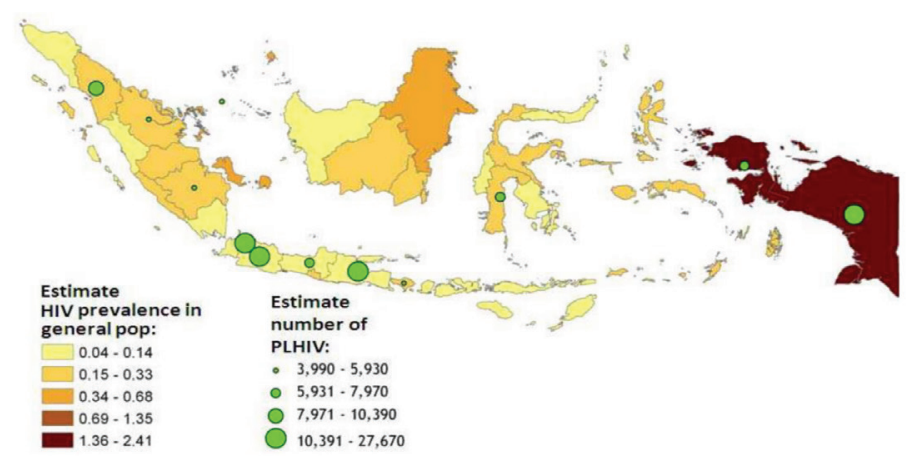

Figure 1 Distribution of HIV and AIDS prevalence, and people living with HIV across Indonesia based on 2009 estimate $^{4}$

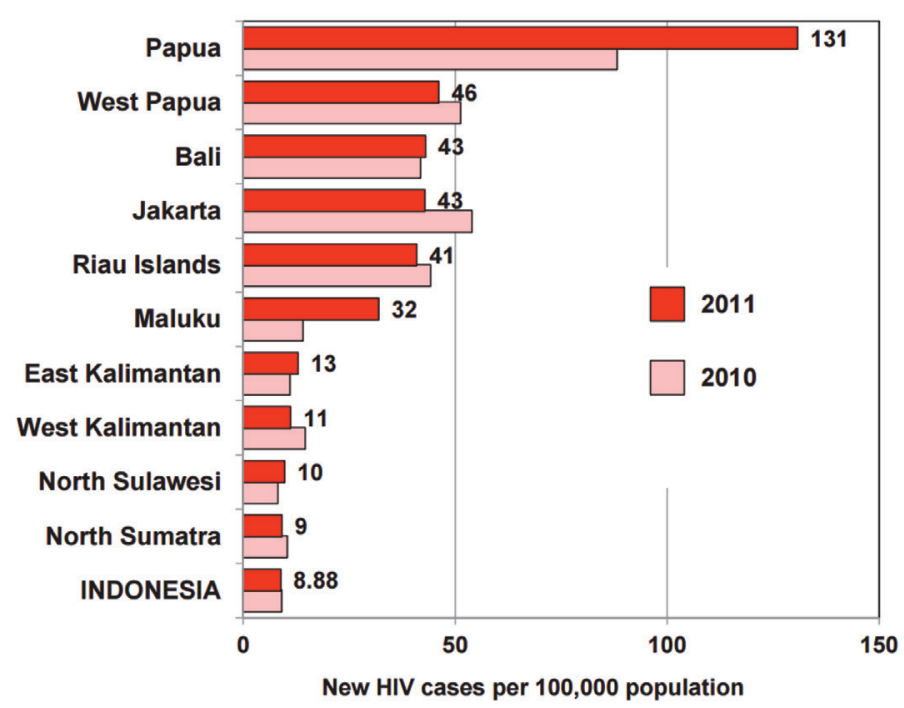

Figure 2 The top ten provinces in new HIV cases per 100,000 population in $2011^{6}$

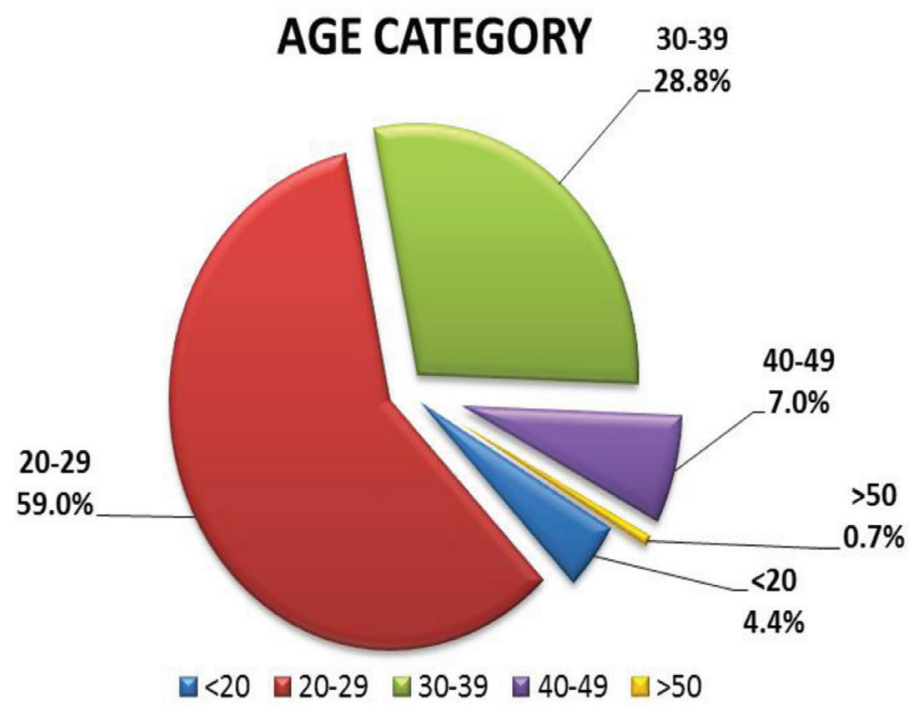

Figure 3 Distribution of patients by age group

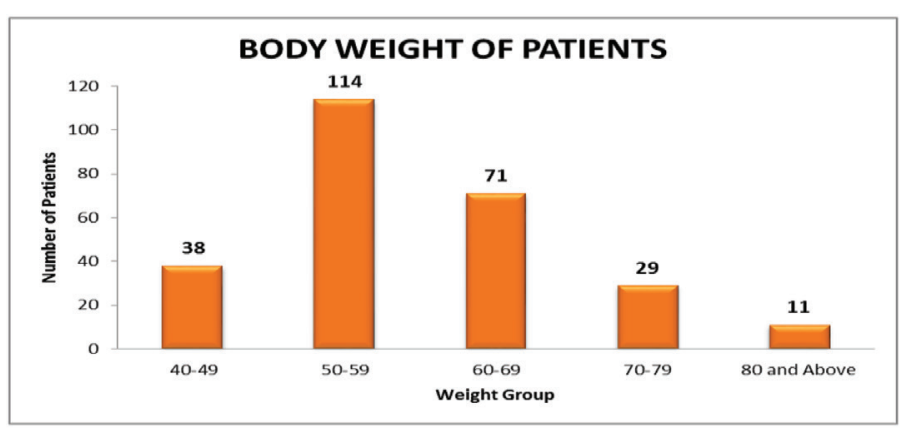

Figure 4 Body weight category

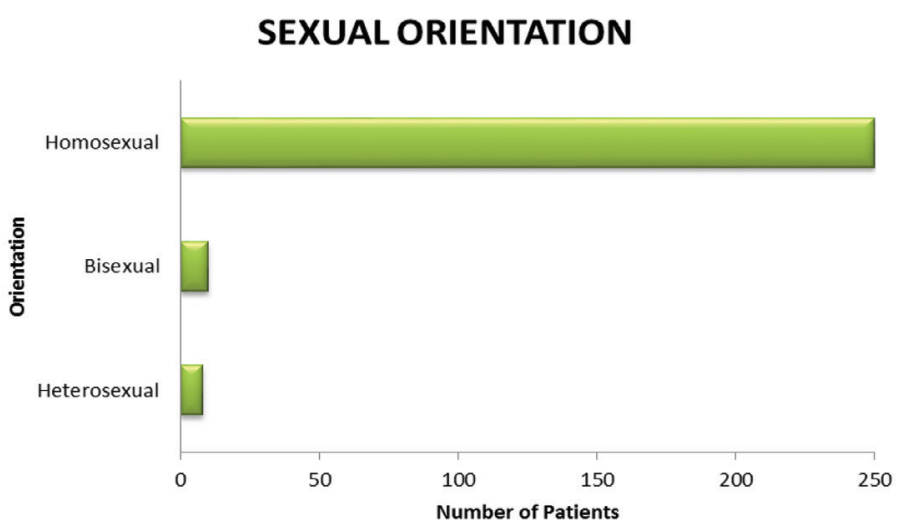

Figure 5 Distribution of Sexual Orientation

\section{EDUCATION LEVEL}

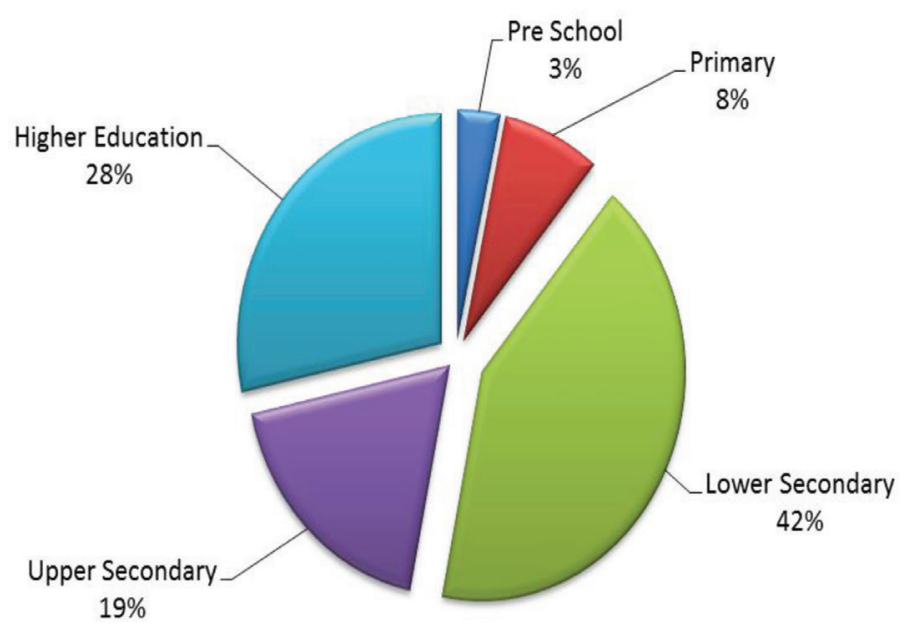

Figure 6 Percentage distribution of education level of patients 


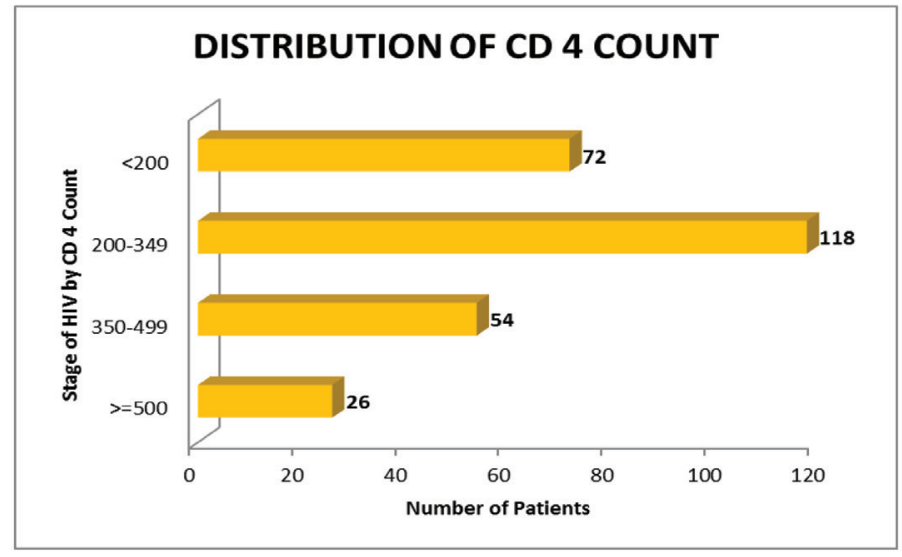

Figure 7 Stages of HIV by CD 4 Count

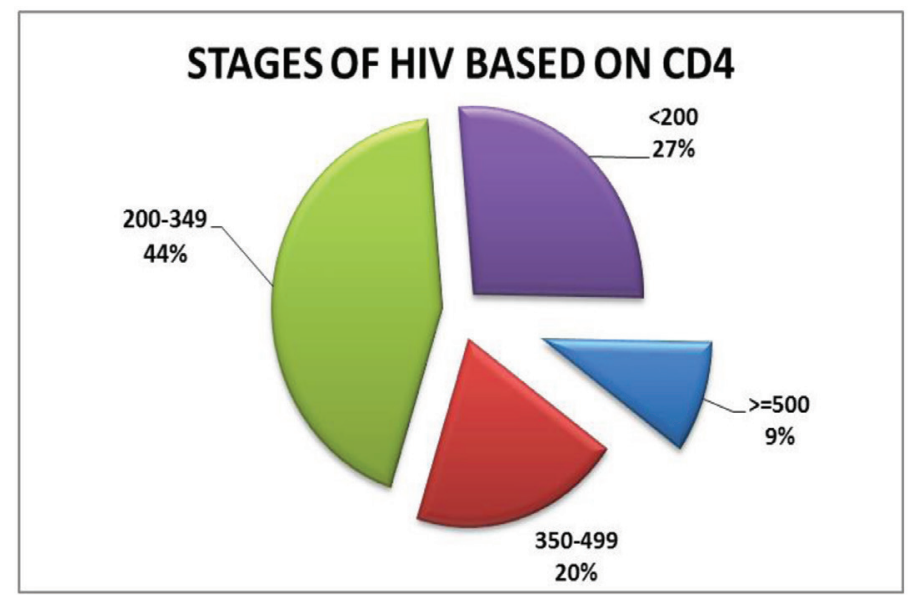

Figure 8 Percentage distribution of Stages of HIV by CD 4 Count

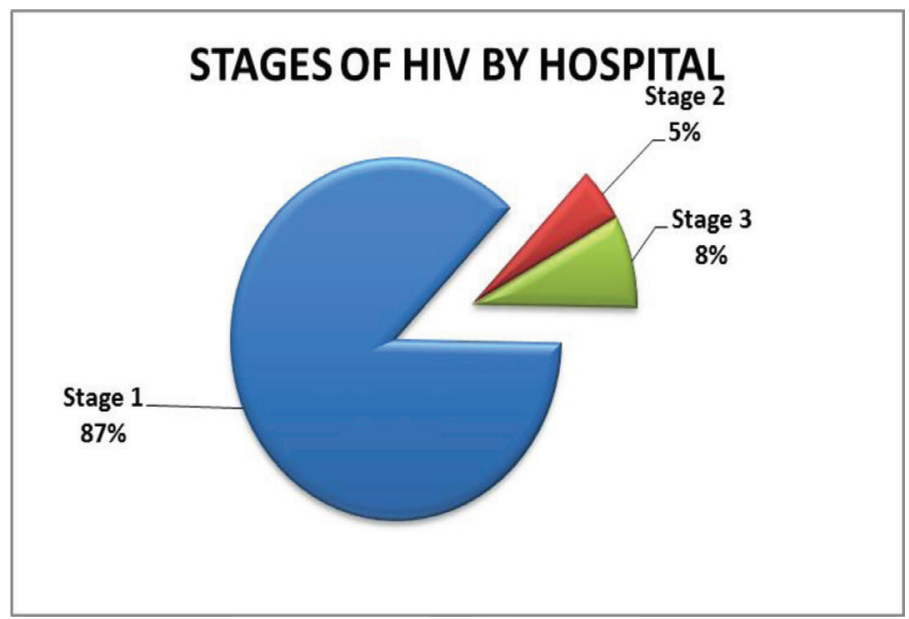

Figure 9 Percentage distribution of stages of HIV by the hospital

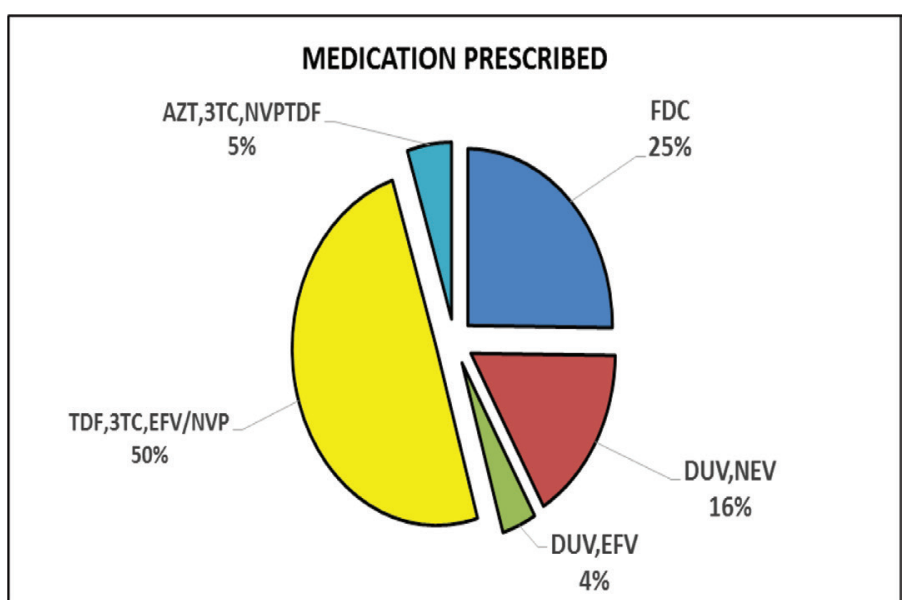

Figure 10 Percentage distribution of a medication prescribed by the hospital

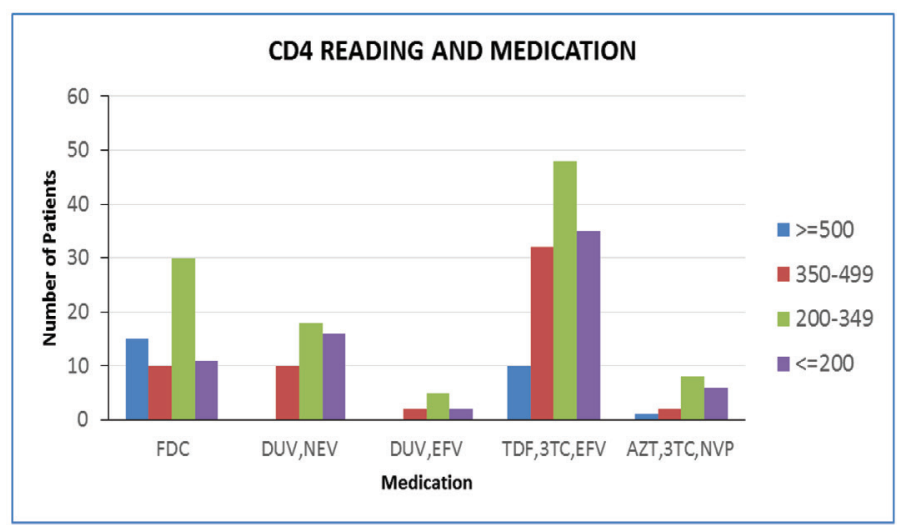

Figure 11 Medication prescribed by hospital comparison with CD 4 levels

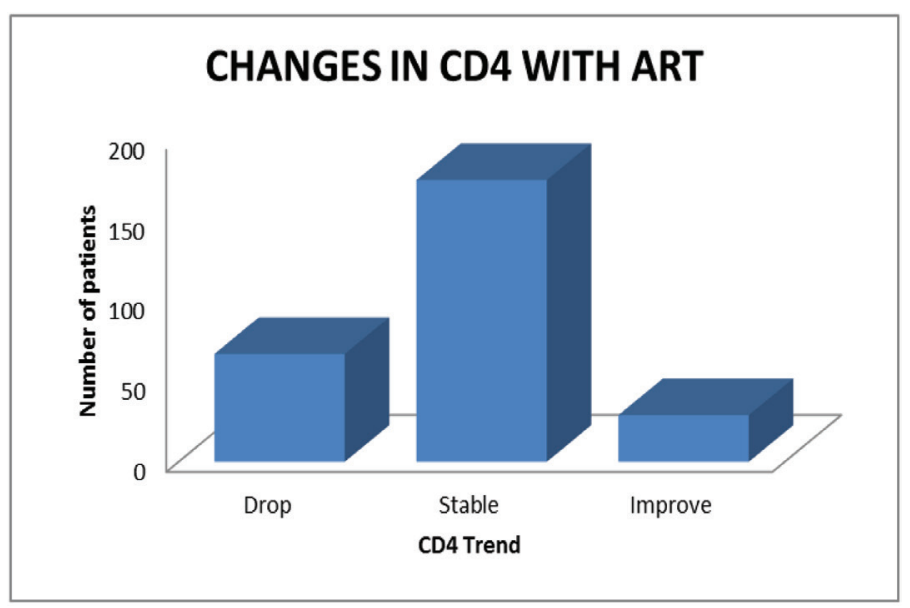

Figure 12 Changes in CD 4 Levels with ART 
patients from obtaining education on safe sex. The fear amongst people creates resistance to HIV testing, embarrassment about seeking treatment, and in some cases, a reluctance to be educated. ${ }^{6}$

\section{Education Level.}

The data showed that $53 \%$ of the patients had a lower secondary education and below as shown in figure 6. There is a high possibility that sex education was not introduced to these patients. Most young people have limited access to sexual and reproductive health information and services. Sex remains a taboo subject that is not openly discussed with parents, teachers, and even with health providers.

Legal restrictions make it difficult for unmarried young people to access sexual and reproductive health services. Other statutory provisions criminalize the dissemination of information on sex education. The promotion of condom use is still problematic in Indonesia; certain regions oppose this on religious or moral grounds. ${ }^{6}$

\section{Clinical Studies of Infected Patients CD4 COUNT}

The CD4 count of the patients was grouped into the four immunosuppression levels and displayed in figure 7 and 8 . It can be noted that $44 \%$ of the HIV patients are in the advance immunosuppression stage and $27 \%$ are in the severe immunosuppression stage.

This could be due to the fact that most of these patients seek medical attention late and fail to perform regular blood tests which could have detected the disease in the early stages. This situation is prevalent in Indonesia where there is a social and religious stigma associated with HIV and the MSM lifestyle. ${ }^{5,7}$

\section{Clinical Staging by Hospital.}

HIV staging is based on the clinical evaluation set by WHO. ${ }^{11,12}$ The clinical staging of HIV patients in this study was shown in figure 9. It could be observed that almost $90 \%$ of the patients have been placed in stage 1 of the WHO clinical staging. It showed that most patients had not developed symptoms that would put them in higher stages.

\section{Comparison of Clinical and Immunosuppression Staging.}

From the data, it can be noted that all the HIV patients in this study are on ART with different medications and dosages. Most patients in this study also responded well to ART will little or no side effects.

It seemed that there was not a strong correlation between the clinical staging and the CD4 levels. The clinical staging had more inclination towards the physical condition of patients. Probably persistent fever and nonreaction to low-level immunosuppression medication would categorize the patients to stage 1 .

Thereon it depended on repeat treatment, and proper collection of data could be helpful for clinical studies to and comparison of medication. The poor correlation observed, however, was consistent with other works reported in similar studies. ${ }^{1,13}$

\section{Comparison of Medication.}

Figure 10 showed the number of patients who were prescribed with ART medication. The distribution of which depends very much on the supply and stock availability. Fixed-dose-combination (FDC) medication have been popular of late, and there are a set of rules for the prescription of FDC. Mostly prescribed to new patients, the FDC is a single pill with a combination of two or more active pharmaceutical ingredients. This drug makes it easy for patients to monitor and administer daily (once a day). Some of the other ART medication used or prescribed is such as TDF - Tenofovir, FTC Emtricitabine, EFV - Efavirenz, 3TC - Lamivudine, and AZT - Zidovudine.

Figure 11 showed the medication types based on the CD4 levels of the HIV patients. Only $25 \%$ of the patients are treated with the fixed-dose combination (FDC) which is a newly introduced single pill a day medication. Most patients are however on ART with tenofovir disoproxil (TDF), lamivudine (3TC) and Efavirenz (EFV) as well as other combinations of drugs.

\section{ART Medication and CD 4 Level Changes.}

An investigation was done on the CD4 count progression of patients based on data from 3 follow up checkups. These check-ups were carried out between 3 to 6 months periods. The information from these investigations was shown in Figure 12.

It appeared that $64 \%$ of the patients recorded stable CD4 levels in follow up checkups and $11 \%$ showed improvements in their CD4 count. However, $25 \%$ of the patients experienced a drop in their $\mathrm{CD} 4$ count. That means that with medication, they did not improve and there needs to be more intervention or change in dedication. There wasn't any specific type of patient that showed these improvements or drops in the CD4 count. So this could be due to the medication or the adherence to the ART regime.

\section{CONCLUSION}

The HIV incidence is a severe matter in Indonesia. The progression of HIV is controlled and made 
manageable by medications and ART. Early diagnosis too will improve the possibility of patients receiving timely treatment, as well as encouraging them to avoid infecting others.

One of the underlying factors for the delayed diagnosis of HIV is the lack of knowledge about the improved prognosis of early ARV treatment and a fear of being stigmatized by the community. Increased availability of HIV testing at hospitals, combined with enhanced knowledge of the prognosis of HIV treatment among key-affected population, and the community at large and may improve earlier testing.

\section{REFERENCES}

1. John, C.N. et al. Is human immunodeficiency virus ( HIV ) stage an independent risk factor for altering the periodontal status of HIV-positive patients? A South African study. BMC Oral Health. 2013; 13(69).

2. Horsburgh, R. Prognostic Indicators for Progression of HIV Disease. In AIDS testing; 1994: 143-151.

3. Tate, D.F. et al. HIV - AIDS : The Neurologic and Cognitive Consequences of HIV-1 Infection. In Handbook of Medical Neuropsychology. 2010; 373-396.

4. National AIDS Commission. Final GARP Report 2012; 2012. Available at: http://www.unaids.org/sites/default/ files/country/documents//ce_ID_Narrative_Report.pdf.

5. Demartoto, A. Pngetahuan, Sikap Dan Perilaku Seksual Laki-laki Yang Berhubungan Seks Dengan Laki-laki (LSL) Dalam Kaitannya Dengan HIV dan AIDS; 2012. Available at: http://argyo.staff.uns.ac.id/2012/12/15/ pengetahuan-sikap-dan-perilaku-seksual-laki-laki-yangberhubungan-seks-dengan-laki-laki-lsl-dalam-kaitannyadengan-hiv-dan-aids
6. UNICEF Indonesia. Responding to HIV and AIDS; 2012:1-4. Available at: http://www.unicef.org/indonesia/ A4-_E_Issue_Brief_HIV_REV.pdf.

7. UNAIDS, 2014. Accelerating the HIV response in Indonesia. Available at: http://www.unaids.org/ en/resources/presscentre/featurestories/2014/ may/20140512indonesia.

8. Rodrigo, C. \& Rajapakse, S. Current status of HIV/AIDS in South Asia. Journal of Global Infectious Diseases. 2009; 1(2): 93-101. Available at: http://www.ncbi.nlm.nih.gov/ pmc/articles/PMC2840955/.

9. KFF Org. The Global HIV/AIDS Epidemic. The Henry J Kaiser Family Foundation; 2015. Available at: http://kff. org/global-health-policy/fact-sheet/the-global-hivaidsepidemic [Accessed January 2, 2016].

10. Rawat, R., Kadiyala, S. \& Mcnamara, P.E. The impact of food assistance on weight gain and disease progression among HIV-infected individuals accessing AIDS care and treatment services in Uganda. BMC Public Health. 2010; 10: $1-8$.

11. World Health Organization. Interim WHO clinical staging of HIV/AIDS and HIV/AIDS case definition for surveillance; 2005.

12. Rabeneck, L. et al. A Simple Clinical Staging System That Predicts Progression to AIDS Using CD4 Count, Oral Thrush, and Night Sweats. 1986; 5: 5-9.

13. Gomber, S. et al. Profile of HIV Infected Children from Delhi and Their Response to Antiretroviral Treatment. Indian Pediatrics. 2011; 48: 703-707.

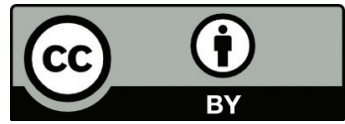

This work is licensed under a Creative Commons Attribution 